\title{
VOCATIONAL HIGH SCHOOL IN INDONESIA FACING ASEAN ECONOMIC COMMUNITY (AEC)
}

\author{
Riris Lawitta ${ }^{1}$, Lasmita Sihaloho ${ }^{2}$, Juli Arianti ${ }^{3}$ \\ Universitas Pendidikan Indonesia, \\ Jalan Setiabudi No.229, Isola, Sukasari, Kota Bandung, Jawa Barat 40154, Indonesia \\ Email: ririslawitta@gmail.com,
}

\begin{abstract}
The implementation of the ASEAN Economic Community (AEC), which has been started since December 2015, is expected to encourage the economic progress of ASEAN and each country to have a positive impact on the economic progress together. Indonesia is the country with the largest population in Southeast Asia and has an everincreasing population growth every year. This is an issue of employment because there is no balance between demand and job supply. The Indonesian people are still not ready to face the AEC seen from the low level of education and the lack of foreign language proficiency, as well as inadequate skills and skills. Vocational education that is prepared to enter the workforce, in fact is not as expected. Graduates of vocational education contribute Indonesia's unemployment rate in 2016 of $9.72 \%$ means that the government needs to improve the quality of education to create qualified human resources capable of competing against AEC. By using descriptive method based on the existing secondary data, the author describes the condition of Vocational High School (SMK) in Indonesia facing AEC. Indonesia is not yet fully prepared in terms of employment. SMK graduates are expected not only able to become a skilled resources but also able to create employment according to their expertise through entrepreneurship.
\end{abstract}

Keywords: Asean Economic Community (AEC); vocational education

\section{INTRODUCTION}

Since 1997, ASEAN has emphasized the need to liberalize trade in services through the implementation of the ASEAN Framework on Trade in Services (AFAS). AFAS aims to substantially eliminate trade restrictions in service among member countries and promote the efficiency and competitiveness of ASEAN service suppliers. In addition to the main obligations of market access and national care, AFAS sets out general guidelines for mutual recognition, refusal of benefits, dispute settlement, institutional mechanisms and other areas of cooperation in the service sector [1]. 
In 2003 to deepen economic integration it was agreed upon the establishment of the ASEAN Economic Community (AEC), to create an integrated market and production base through free trade, foreign direct investment, skilled labor, and freer capital flow.

The implementation of AEC 2015 aims to create a single market and stable, prosperous, highly competitive and economically integrated production base with effective regulation for trade and investment, in which there is free flow of goods, services, investments, and capital goods and their support freedom of movement of business actors and labor [2]. Theoretically, liberalization in the market of goods, services, capital and labor will increase labor productivity, because it will create conditions that encourage companies to allocate resources more efficiently.

The implementation of the ASEAN Economic Community which has been started since December 2015 is expected to push the economic progress of ASEAN and each country together to have a positive impact on the economic progress. This implementation will focus on 12 priority sectors, consisting of seven sectors of goods (agriculture, electronic equipment, automotive, fishery, rubber-based industries, woodbased industries and textiles) and five service sectors (air transport, health services, , logistics, and the information technology industry or e-ASEAN).

Each country prepares its own resources to face the opportunities and competition in the economic integration, including Indonesia. Ministerial Regulation Number PPN No. 2017 on the Strategic Plan of the Ministry of National Development Planning / National Development Planning Agency 2015-2019 notes that within the next five years one of the main external challenges is the coming into effect of the ASEAN Economic Community Blueprint 2015 and 2025.

The competitiveness of Indonesia in facing the AEC competition is determined by the outcome of human resources development. High quality human resources and high competitiveness is the main capital to facilitate the development of the country. Countries need to pay attention and develop resources that support the development of human resources, such as through education either formal, non formal, or informal education. Through human resource education has the opportunity to learn, develop and improve the capacity that is then useful as an investment. Marshall [3] and Smith [4] argues that education and training are an investment in human and human resources is the most valuable resource of all resources. According to Becker (1994) states that capital is not only "tangibles" but other forms of "intangibles" that generate long-term incomes and benefits such as education. Education, training, and health are the most important investments in human investment. Human capital analysis assumes that schools can increase income and productivity through knowledge, skills, and how to solve problems.

Law Number 20 Year 2003 states that Education is a conscious and planned effort to create an atmosphere of learning and learning process so that learners actively 
develop their potential to have spiritual spiritual strength, self-control, personality, intelligence, noble character, and the necessary skills himself, society, nation and state.

One of the efforts of the state in the fulfillment of qualified middle-level human resources is through the development of vocational education [5]. This is in agreement with those disclosed by Slamet PH [6] which states that all countries are investing in vocational education and technical training (TVET). The higher the level of state income, generally the higher the proportion of students enrolled in the vocational institutions (TVET). Educational growth affects economic growth and vice versa, economic growth affects education growth [7, 8, 9].

The fulfillment of a productive workforce can be done with employment education. Non-formal and informal employment education is conducted at the training center, community center, work training institute, work training course, and others. While formal employment education is generally done at the level of secondary education and higher education with the type of vocational education, vocational, professional and academic according to the mandate of the National Education System Act No. 20 of 2003.

Law Number 20 Year 2003 Article 15 states that vocational education is secondary education which prepares students primarily to work in a particular field. All students who graduate from vocational schools are expected to have the skills, ready to enter and work into the industrial world. Ironically, the Central Bureau of Statistics data shows SMK graduates in Indonesia occupy the second highest position of unemployment contributors. In addition, Global Entrepreneurship Monitor 2015-2016 [10] data shows that Indonesia Human Resources Index is still low in sixth position in ASEAN and ranked 69th in the world. Singapore is in the top position for the ASEAN region.

Vocational education is considered capable of answering the problems of labor and unemployment $[11,12,13]$. Evans [14] further states that vocational education is part of the educational system that prepares a person to be better able to work in one occupational group or one field of work than any other field of work. Vocational education also helps reindustrialization through three main groups: training young people to work, training current workers, and returning to the workforce.

Vocational education has different characteristics from general education, whether viewed from the criteria of education, the substance of the lesson, and its graduates. The criteria inherent in the vocational education system according to Finch and John $\mathrm{R}$ Crunkilton [15], among others (1) the orientation of education and training; (2) justification for existence and legitimacy; (3) focus on curriculum content; (4) learning success criteria; (5) sensitivity to community development; and (6) cooperative relations with the community. Nolker states that in choosing the substance of the lesson, vocational education should always follow the development of science and technology, community needs, individual needs, and employment.

The purpose of vocational education includes four main dimensions, namely: (1) Developing basic human qualities that include the quality of thinking power, qolbu 
power, physical power; (2) Developing instrumental quality / functional quality, namely mastery of science, technology, art, and sport; (3) Strengthen identity as the nation of Indonesia; and (4) Maintaining the survival and development of the world [6].

So the purpose of this paper is to describe the readiness of vocational education graduates in facing the MEA. In the face of competition MEA President Jokowi began to fix the SMK through Inpres No. 9 of 2016 by preparing middle-level workers from SMK graduates should be given a record in facing challenges and issues-isuglobal, then revitalization of SMK needs to be done programmed and structured. With this policy, SMK is expected to be able to bear and be the answer to the problem of human resources ready to work middle level in the middle of Indonesia facing competition MEA to be resolved.

\section{METHOD}

This research is quantitative using descriptive method, where the author describes labor force condition in Indonesia based on graduate level of vocational education that has been rescued in the last three years and describes the condition of entrepreneurship in Indonesia. Researchers observed the phenomenon without direct intervention. Researchers connect the variables of the vocational and entrepreneurial workforce in facing the ASEAN Economic Community. The relationship in this situation is the same as the explanation of Boswel and Cannon (2011) and Mitchell \& Jolley (2009).

The collected data is the result of the secondary time series data library published by Global Entrepreneurship Monitor (GEM), BPS, Ministry of Manpower, and various related publications.

\section{RESULTS AND DISCUSSION}

Vocational High School Education (SMK) as a middle-level vocational education has a big role in planning and creating professional and productive human resources in order to prepare them as a workforce. This is consistent with Lauglo and Maclean [16] that the vital role of vocational education in printing employment has a very strategic role that will fill the needs of work in the business world and industry.

However, in reality, vocational graduates until now still not able to answer the problems of the labor needed by the world of work. Job opportunities offered by the labor market are still largely unfilled. This is evident from existing education graduates not being absorbed in the labor market. Based on data from the Central Bureau of Statistics (BPS) shows the unemployment rate in August 2017 based on the level of education graduates SMK graduates are ranked second highest ie 13.83 percent which can be seen in Graph 1 and graph 2 showing the number of labor force and unemployment rate open in year 2014 - 2017. This shows the gap between the demand 
in the world of work with the supply of labor from educational institutions of one vocational high school (SMK).

Based on data from the Central Bureau of Statistics (BPS) shows the unemployment rate in August 2017 on SMK graduates are ranked second highest ie $13.83 \%$ which can be seen in Graph 1 and Graph 2 showing the number of labor force and unemployment rate open in year 2014 - 2017. This shows the gap between the demand in the world of work with the supply of labor from educational institutions of one vocational high school (SMK).

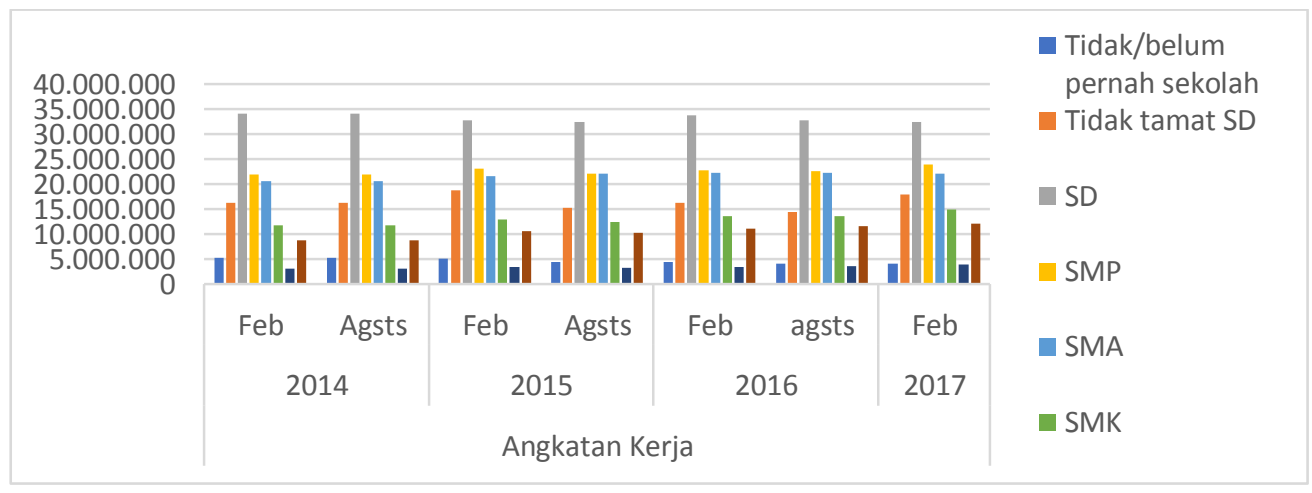

Graphic 1. Total of Laborforce $2014-2017$

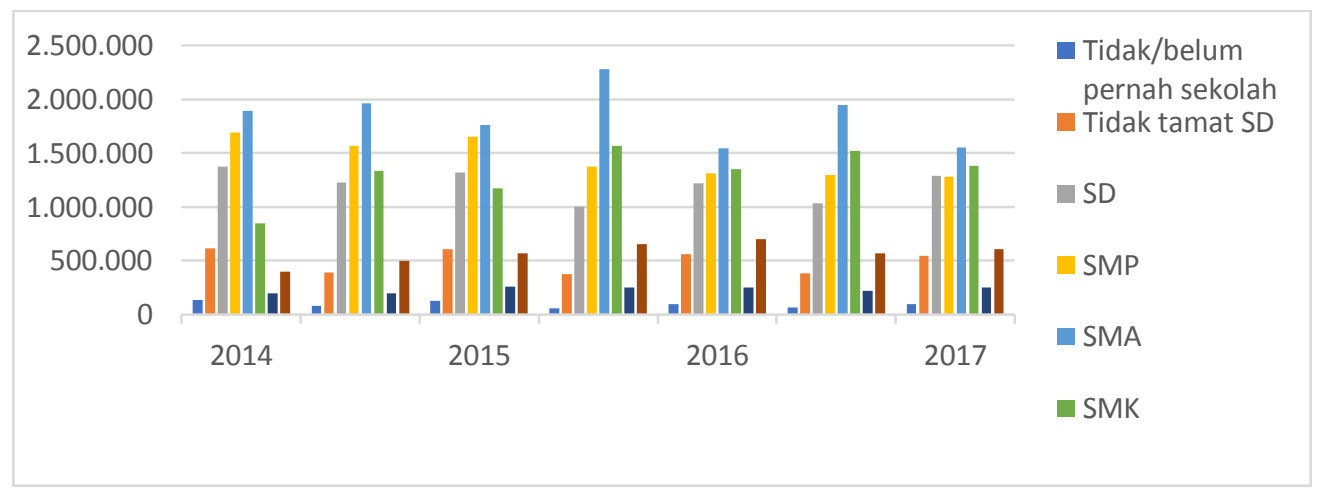

Graphic 2. Total of Unemployment $2014-2017$

This is also in consistence with the research of Siti Mariah \& Machmud Sugandi [17] condition of the readiness of graduate of Vocational High School (SMK) currently shows there are gaps of soft skills of vocational graduates with the need of manpower in 
industry or business. The following Gap analysis of demand (Labor industry) and supply (Graduate SMK)

\begin{tabular}{|c|c|c|}
\hline Sistem kerja di industri garment & $\begin{array}{l}\text { Kesenjangan Soft } \\
\text { Slkills }\end{array}$ & Proses pembelajaran di SMK \\
\hline $\begin{array}{l}\text { Proses produksi bersifat continuous } \\
\text { line flow sehingga setiap operasi } \\
\text { saling bergantung satu dengan yang } \\
\text { lain. }\end{array}$ & $\begin{array}{c}\text { Kerjasama } \\
\text { komunikasi } \\
\text { Kepemimpinan }\end{array}$ & $\begin{array}{l}\text { Pembelajaran praktek bersifat } \\
\text { individual dengan komunikasi satu } \\
\text { arah dari guru ke siswa }\end{array}$ \\
\hline $\begin{array}{l}\text { Menggunakan prinsip fundamental } \\
\text { yaitu Kaizen (Ringkas, Rapi, Resik, } \\
\text { Rawat, Rajin) dan aman }\end{array}$ & $\begin{array}{l}\text { Disiplin } \\
\text { Tanggung Jawab } \\
\text { Teliti } \\
\text { jujur } \\
\text { Ketahanan mental }\end{array}$ & $\begin{array}{l}\text { Konsep } \mathrm{K}_{3} \text { masih berupa teori dan } \\
\text { belum diterapkan secara konsisten } \\
\text { dalam pembelajaran praktik }\end{array}$ \\
\hline $\begin{array}{l}\text { Persaingan industri dan perdagangan } \\
\text { mengacu pada enam faktor penentu } \\
\text { yaitu: harga, mutu, disain (selera), } \\
\text { waktu pemasokan (delivery time), } \\
\text { pemasaran, dan layanan (services). }\end{array}$ & $\begin{array}{l}\text { Daya saing Ulet } \\
\text { Adaptasi } \\
\text { semangat } \\
\text { Ketahanan mental }\end{array}$ & $\begin{array}{l}\text { Pengukuran hasil kerja berdasarkan } \\
\text { faktor nilai } \circ-100\end{array}$ \\
\hline $\begin{array}{l}\text { Pengukuran kualitas kerja yaitu: baik } \\
\text { (accepted) dan jelek (rejected). } \\
\text { Keberterimaan kualitas hasil kerja } \\
\text { mempengaruhi harga jual, jika gagal } \\
\text { akan menjadi kerugian atau lost. }\end{array}$ & $\begin{array}{l}\text { Daya juang } \\
\text { Daya saing } \\
\text { Ketahanan mental }\end{array}$ & $\begin{array}{l}\text { Kualitas hasil kerja untuk nilai } \\
\text { prestasi akademik }\end{array}$ \\
\hline $\begin{array}{l}\text { Proses produksi menggunakan } \\
\text { specification sheet }\end{array}$ & $\begin{array}{l}\text { Responsif } \\
\text { Cermat } \\
\text { Teliti Daya juang }\end{array}$ & $\begin{array}{l}\text { Pembelajaran praktek tidak } \\
\text { menggunakan work sheet. } \\
\text { Guru menjelaskan tugas secara } \\
\text { lisan, dan siswa mengerjakan } \\
\text { hanya dengan kira-kira }\end{array}$ \\
\hline
\end{tabular}

Source: Siti Mariah dan Machmud Sugandi, 2010

The high unemployment rate of vocational graduates shows that vocational education is not ready to face the AEC. Unemployment in Indonesia is the highest among other 10 ASEAN member countries, including the unpreparedness of skilled labor in facing the AEC. Working demands that are not in relevant with the readiness of SMK graduates which opposite with the mental candidates of middle-level workers, resulting in a lack of self-confidence in finding work. Therefore, students of SMK need to trainee and form their character and competence during school. In addition, improving mobility, adaptability, and labor productivity are indispensable in education and training as a very important instrument for vocational schools. Such contributions will enhance the competitiveness of enterprises and improve labor market imbalances [11]. Technical Vocational Education and Training (TVET) consists of all skill transfers, formal and informal, which are necessary in enhancing the community's productive activities (Canoy in Agrawal, 2013).

One of the ways that can be taken to improve the economy and reduce the unemployment rate in SMK is through entrepreneurship. Graduates of vocational secondary education (SMK) should be able to apply the skills they have through entrepreneurship. 
In addition, in facing the MEA and the globalization challenging in addition to requiring a workforce with working skills also required skills to face change and exploit the change itself. Therefore, SMK graduates are expected to have hard skill and soft skill skills in order to compete in the world of work and globally. The debriefing is not only knowledge but soft kill ability which is also a very important competence to be mastered in accordance with the demands of existing work.

Thus the development of entrepreneurship in SMK must be do comprehensively through hard skills and soft skills that appropriate to the development of character and entrepreneurial culture. Juridically this is in accordance with Presidential Instruction (Inpres) No. 9 of 2016 revitalization of SMK is needed to improve the quality of human resources. The Inpres commissioned the Ministry of Education and Culture (Kemendikbud) to make a study of SMK development; perfecting and aligning the SMK curriculum with competencies according to the users of the graduate (link and match).

In addition, the Ministry of Education and Culture has the duty to increase the number and competence for SMK educators and education personnel; enhance cooperation with ministries / agencies, local government, business and industry; and improving access to graduate certification of SMK and SMK accreditation; and formed a working group on the development of SMK [19]. A competent and skilled workforce one of whom was born of Vocational Education and training is of high quality and relevant to the constantly growing demands of Business and Industry [18].

\section{CONCLUSIONS AND RECOMMENDATIONS}

Graduates of vocational education (SMK) have not been able to compete in AEC. There are many things that must be correcting to prepare qualified human resources in order to compete. Vocational education can play a key role in economic development if its programs can be integrated with government regulation, policy, planning and budgeting. The quality and relevance of education is reflected in the ability to form graduates' competencies in order to become productive and self-employed workers. Indonesia is not fully prepared for ASEAN's economic integration. The need for improvement in some aspects, including the quality of human resources.

The opportunities for skills education, skills and professions must be large and evenly linked to the centers of industrial economic development, the utilization of science and technology, and the upgrading of life skills appropriate to the potential of the region, and the principle of lifelong learning. The society is expected to be able to change the mindset of as job seekers into job creators through entrepreneurship. SMK graduates are expected not only able to become a skilled workforce but also able to create employment according to their expertise. 


\section{REFERENCE}

[1] Rafaelita M. Aldaba. (2015). ASEAN Economic Community 2015: Labor Mobility and Mutual Recognition Arrangements on Professional Services (PIDS Discussion Paper Series No. 2013-4). Makati City, Philippines. Retrieved from http://hdl.handle.net/10419/126921.

[2] Chia, S. (2013). The ASEAN Economic Community: Progress, Challenges, and Prospects. SSRN Electronic Journal. https://doi.org/10.2139/ssrn.2346058

[3] Marshall, A. (1890). The Principles of Economics. New York: Maxmillan.

[4] Smith, A. (1827). An Inquiry into the Nature and Causes of the Wealth of Nations. Oxford University. University Press for T. Nelson and P. Brown. https://doi.org/10.1016/0003-6870(73)90259-7

[5] Damarjati, T. (2016). Konsep Pembelajaran di Sekolah Menengah Kejuruan. Retrieved June 30, 2017, from https://psmk.kemdikbud.go.id/konten/1869/konsep-pembelajaran-di-sekolah-menengahkejuruan

[6] Slamet PH. (2009). Peranan Pendidikan Vokasional Dalam Pembangunan Ekonomi. Cakrawala Pendidikan; No 2 (2011): Cakrawala Pendidikan Mei 2011, Th. Xxx, Edisi Khusus Dies Natalis, 189-203. https://doi.org/10.21831/cp.v0i2.4227

[7] Adiwikarta, S. (1988). Sosiologi Pendidikan: Isyu dan Hipotesis tentang Hubungan Pendidikan dengan Masyarakat. Departemen Pendidikan dan Kebudayaan. Jakarta.

[8] Bowles, S., \& Gintis, H. (2011). Schooling in Capitalist America Revisited. Source: Sociology of Education (10th ed., Vol. 75). Canada: Lannan Foundation and the Wallace Global Fund. https://doi.org/10.2307/3090251

[9] Saripudin, D. (2005). Mobilitas dan Perubahan Sosial. Bandung: Masagi Foundation.

[10] Nawangpalupi, C. B., PawitNawangpalupi, C. B., Pawitan, G., Gunawan, A., Widyarini, M., Putri, F. E., \& Iskandarsjah, T. (2016). Entrepreneurship In Indonesia: Conditions and Opportunities for Growth and Sustainability. Bandung.

[11] Caillods, F. (1994). Converging trends amidst diversity in vocational training systems. International Labour Review, 133(2), 241. Retrieved from http://proquest.umi.com/pqdweb?did=233445\&Fmt=7\&clientId=29974\&RQT=309\&VName=PQ D

[12] Eichhorst, W., Rodríguez-planas, N., Schmidl, R., \& Zimmermann, K. F. (2015). A Road Map To Vocational Education And Training In Industrialized Countries. ILR Review, 68(2), 314-337. https://doi.org/10.1177/0019793914564963.

[13] Hanushek, E. A., Schwerdt, G., Woessmann, L., \& Zhang, L. (2014). General Education, Vocational Education, and Labor-Market Outcomes over the Life-Cycle. World Bank Policy Research Working Paper, (7095), 1-63. https://doi.org/10.3368/jhr.52.1.0415-7074R

[14] Evans, R. E. (1981). Vocational Education and Reindustrialization. Research in Vocational Education and Training, 60(1), 53-63. Retrieved from http://encore.exeter.ac.uk:61080/jstor/stable/10.2307/41427696?ref=searchgateway:66effe317bbe1da6712a121a51061b71

[15] Finch, C. R., \& John R Crunkilton. (1999). Curriculum Development in Vocational and Technical Education. Planning, Content, and Implementation. Allyn and Bacon, 160 Gould Street, Needham Heights, MA 02494.

[16] Lauglo, J., \& Maclean, R. (2005). Vocationalised Secondary Education Revisited. Netherlands: Springer Netherlands.

[17] Agrawal, T. (2013). Vocational education and training programs (VET): An Asian perspective. Indira Gandhi Institute of Development Research (IGIDR).

[18] Becker, G. S. (1994). Human Capital Revisited. In G. S. Becker (Ed.), Human Capital: A Theoretical and Empirical Analysis with Special Reference to Education (3rd ed., pp. 15-28). The University of Chicago Press. Retrieved from http://www.nber.org/books/beck94-1

[19] Kementerian Tenaga Kerja. (2017). Revitalisasi SMK Untuk Produktivitas dan Daya Saing Bangsa. Retrieved July 28, 2017, from http://kemnaker.go.id/berita/berita-kemnaker/revitalisasi-smk-untukproduktivitas-dan-daya- saing-bangsa 